\title{
ENHANCING BIRD BIODIVERSITY THROUGH IMPROVED WATER MANAGEMENT IN A VIET NAM WETLAND NATIONAL PARK
}

\author{
Chu Van Cuong ${ }^{1 *}$, Peter Dart ${ }^{2}$, Sharon Brown ${ }^{2}$, Tran Van Thang ${ }^{3}$ and Vo \\ Thi Minh Le ${ }^{4}$ \\ *Corresponding author: \\ ${ }^{1}$ Institute for Sustainable Natural Resource Management and Biodiversity Conservation, \\ Viet Nam \\ ${ }^{2}$ School of Agriculture and Food Sciences, The University of Queensland, Australia \\ ${ }^{3} \mathrm{U}$ Minh Thuong National Park, Viet Nam \\ ${ }^{4}$ Institute of World Economics and Politics, Viet Nam Academy of Social Sciences, Viet Nam
}

\section{ABSTRACT}

U Minh Thuong National Park, one of the two largest remaining peat swamp, melaleuca forests in Viet Nam is a very Important Bird and Conservation Area because of its diverse wetland habitats. A devastating forest fire in 2002 resulted in a new regime of fire control based on an imposed permanent flooding regime over large areas of the Park that led to severe wetland and forest degradation. This in turn negatively impacted on bird species diversity and populations. In 2009, the Government of Viet Nam and the park authority adopted an improved water management practice. A survey four years later recorded two new species in the list of 159 bird species for the park. Of these, 25 threatened species were using the wetland park and adjacent Buffer Zone for living and feeding habitat. Based on the largest count occurring during three continuous days, the water bird population in the bird colony in 2013 increased by 33 per cent compared to the 2009 level. The positive response of avifauna to the changes in U Minh Thuong with respect to the hydrology of seasonally flooded melaleuca wetland forest indicates the need to understand how the 'normal' wetland processes operate in support of biodiversity conservation before modifying them for fire management.

Key words: Water birds, wetland birds, wetland restoration, hydrological changes, U Minh Thuong

\section{INTRODUCTION}

Although wetlands cover only ca. 9 per cent of the world land area, they are globally significant ecosystems for biodiversity conservation of plants and animals, particularly waterfowls (Zedler \& Kercher, 2005; Bobbink et al., 2006). However, these natural ecosystems are inadequately protected from land conversion to agriculture, water drainage and fire (Kingsford \& Thomas, 2004; Yule, 2010; Hawa et al., 2016). Consequently, over half of these global wetlands have already been lost as a result of human activities, particularly in densely populated regions, where more than 80 per cent of the wetlands have been lost or severely degraded (Bobbink et al., 2006; Davidson, 2014). As a result, wetland biodiversity is under high risk and many species are threatened with extinction (Millennium Ecosystem Assessment, 2005).

The Mekong Delta is a major rice and aquaculture production area in Viet Nam, and was one of the largest natural wetland ecosystems of melaleuca (Melaleuca cajuputi) and mangrove forest in the world before 1900 (Thinh, 2003; Biggs, 2005). However, human disturbance through wetland reclamation programmes for agricultural intensification in the Delta resulted in significant loss and fragmentation of the high environment and conservation values of the wetland (Buckton et al., 1999; Thinh, 2003; Buckton \& Safford, 2004). In 1998, approximately 94 per cent of the Mekong Delta's natural wetland area had been artificially reclaimed for agriculture and aquacultural production (Thinh, 2003). A study in 2015 found only 1.7 per cent of the total of four million ha of natural wetland in the Mekong had been left (Hoang et al., 2017).

U Minh, one of the three most important wetland regions in the Mekong Delta, was covered by extensive melaleuca forest (Buckton \& Safford, 2004; Biggs, 2005). However, since 1980 it has experienced a large 
loss of forested area, and wetland degradation through expansion of rice and aquaculture production, and canal development for irrigation (Biggs, 2005; Viet Nam Environmental Protection Agency, 2005). To control this land conversion, wetland protected areas have been established by the Central Government in the Mekong Delta to conserve biodiversity and important wetland bird areas in particular since the 1990s (Buckton et al., 1999; Viet Nam Environmental Protection Agency, 2005).

U Minh Thuong National Park (UMTNP) houses one of the two largest remaining peat swamp melaleuca forests in Viet Nam, a unique ecosystem in the Indochina region and recognised as the most Important Bird and Conservation Area in Viet Nam (Buckton et al., 1999). The park is also the home of the largest water bird colony in the Mekong region (Hoa, 2002). However, the rich avifauna of the park was negatively affected by forest clearance and wildfire. Especially, inappropriate water management practice for fire prevention, which was only focused on preserving tree species based on a deep and permanent flood regime, led to further wetland and habitat degradation in UMTNP (Biggs, 2005; 2011; Dang, 2009; Huong, 2011).

In this article, we present the impacts to avifauna of hydrological changes imposed from water management of UMTNP and management options which might enhance biodiversity conservation and fire prevention in UMTNP and other similar places in the Mekong Delta and the world.

\section{WETLAND MANAGEMENT CHALLENGE IN U MINH THUONG NATIONAL PARK U Minh Thuong National Park}

U Minh Thuong National Park (UMTNP) is located on the upper part of the U Minh region from 9031'16"9039'45" North and 105003'6"-105007'59" East. It is $365 \mathrm{~km}$ southwest from Ho Chi Minh City and approximately $60 \mathrm{~km}$ from Rach Gia, the capital city of the Kien Giang Province. The core zone of UMTNP covers an area of 8,038 ha, recognised as a national historical site (Biggs, 2005; Kien Giang Province People's Committee, 2005), an Asian Heritage Park and Ramsar site.

$\mathrm{U}$ Minh is a flat region with average elevation of $0.5 \mathrm{~m}$ above mean sea level. Soils in the region were formed by deposits of alluvial sediments from the Mekong River 10,000 years ago (Hashimoto, 2001). After initially trapping sediment to form soils, mangrove forests deposited large amounts of organic material gradually raising the ground level so that it was no longer influenced by sea water. Under the now dominant fresh water condition, melaleuca forest was established replacing the mangrove forest while continuing to accrete organic material to the developing soil forming two main soil types - acid sulphate soils and peatland (Care, 2001; Hashimoto, 2001).

\section{Climate and hydrological conditions}

Located in the highest rainfall area in the Mekong Delta, $\mathrm{U}$ Minh region receives an average of 2,200-2,400 mm annually, but the rainfall is unevenly distributed with a pronounced dry season (from December to April) receiving only about 5 per cent $(110-120 \mathrm{~mm})$ of the total annual rainfall, while the evaporation in this period is very high $(587-614 \mathrm{~mm})$ due to high daily temperatures reaching to $38^{\circ} \mathrm{C}$ (Huong, 2011).

The hydrology of the region is characterised by wet seasonal inundation and surface soil drying during the dry season (Ngan \& Hien, 1987; Bao, 2011; Anh, 2013). This natural condition is appropriate for establishment and evolution of the wetland ecosystem dominated by melaleuca (Melaleuca cajuputi) forests and peatland formation and accumulation (Quynh, 2011). However, it was artificially changed by the creation of an extensive canal system for crop irrigation, transportation and rural development (Biggs, 2005; 2011; Dzung \& Co, 2011).

\section{History of forest loss and fragmentation}

In the 1930s, melaleuca forest in the U Minh region covered an area of about 142,00o ha (Dzung, 2002; Biggs, 2005). As one of the three biggest bases for the revolutionary forces in South Viet Nam during the Indochina wars, the forest in U Minh was damaged by Agent Orange and Napalm bombs in the second Indochina war (Biggs, 2005), but approximately 100,000 ha of natural melaleuca forest remained until 1975 (Dzung, 2002). After this time, the forest was rapidly cleared to meet the demand for economic development, and agricultural and aquaculture expansion (Dzung, 2002; Biggs, 2005). In 1978, the Kien Giang Province dug an outer dyke and associated canals with a $60 \mathrm{~km}$ perimeter to enclose and thereby protect the last area of 21,800 ha of natural melaleuca forest. However, this effort was not effective in stopping illegal deforestation. In 1992, in parallel with establishing the U Minh Thuong Nature Reserve, Kien Giang provincial authority continued to build a second $38 \mathrm{~km}$ of inner dykes and canals that ran parallel to the outer dyke (Figure 1). This new dyke system also defined the park's boundary, aimed at strictly conserving the last remaining area of 8,038 ha of wetland and melaleuca forest under the National Protected Area system (Dzung, 2002) . 


\section{Pressure from land use conversion}

The area between the inner dyke and outer dyke, an area of 14,192 ha, was managed as a buffer zone around the core protected area zone. Most people live along the 22 canals in the buffer zone running between the canals of the inner and outer dyke (Dzung, 2002). In the buffer zone, each household was allocated an average area of 4.0 ha of land by the province and mandated to maintain 2.0 ha for melaleuca plantation, 1.0 ha for fish ponds and 1.0 ha crop production. In 2000, there were 3,022 households with 16,227 people living in the buffer zone (Chandler et al., 2000) and by 2013 there were 3,675 households and 18,852 people (Tuyen, 2013). Although these households received provincial government support for socio-economic development and livelihood improvement, many are still poor forestdependant people (Dang, 2009; Tuyen, 2013). This posed a significant challenge to the biodiversity conservation of the park due to illegal access for wildlife hunting, fishing and collecting honey (Biggs, 2005; Dang, 2009; Tuyen, 2013; Nuwer \& Bell, 2014).

\section{Impacts of forest fire and inappropriate water management}

Development of an intensive canal system surrounding a small melaleuca forest area altered the natural hydrological condition in the park and surrounding areas. In the dry season, the depth to the underground water table increased due to the large demand for irrigation and natural evaporation. This resulted in drying out of the peaty soil and made it prone to wildfire (Dzung \& Co, 2011; Bao, 2011; Anh, 2013).

In March 2002, only two months after the Nature Reserve was upgraded to National Park status, a devastating fire occurred destroying approximately 3,000 ha of melaleuca forest that represented 80 per

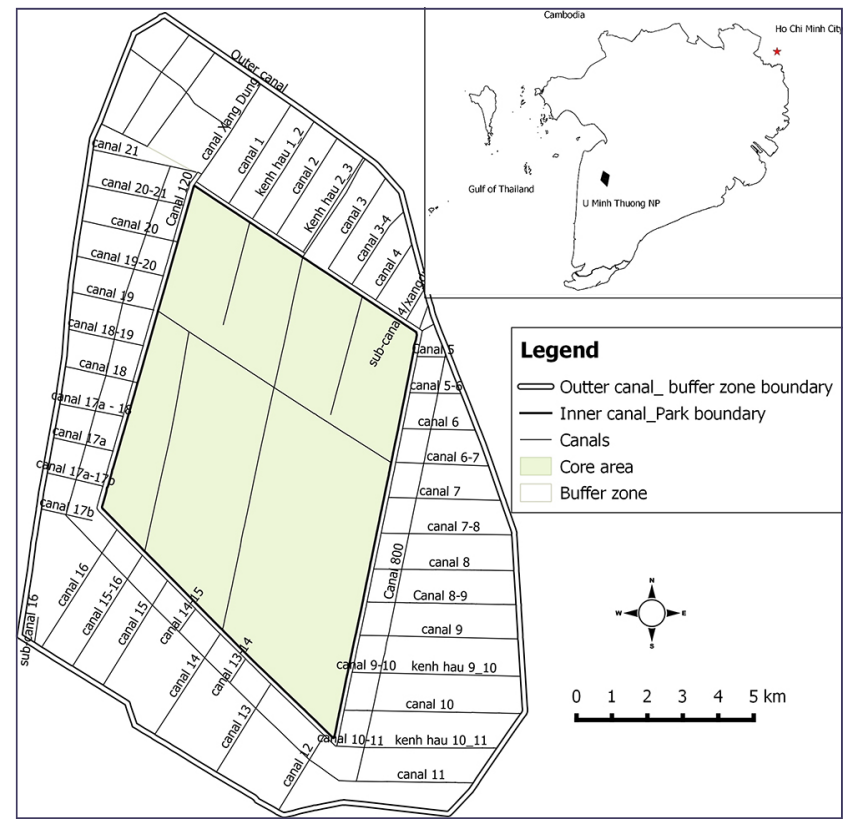

Figure 1. Map of the dense and extensive canal system established by Kien Giang Province in the wetland of the core zone of UMTNP and surrounding buffer zone.

cent of the primary forest on the peatland of the park (Dzung \& Co, 2011; Thinh, 2011). This fire not only significantly reduced the natural forest area but also destroyed wetland habitat and bird nesting sites (Sanders, 2002). There was also long-term environmental damage to the soil and freshwater ecosystem resulting from the large volume of salt water pumped into the park for firefighting (Sanders, 2002; Dzung \& Co, 2011).

This fire event was considered a national disaster and as such the central government, province and conservation organisations paid it great attention. The fear of a repeat

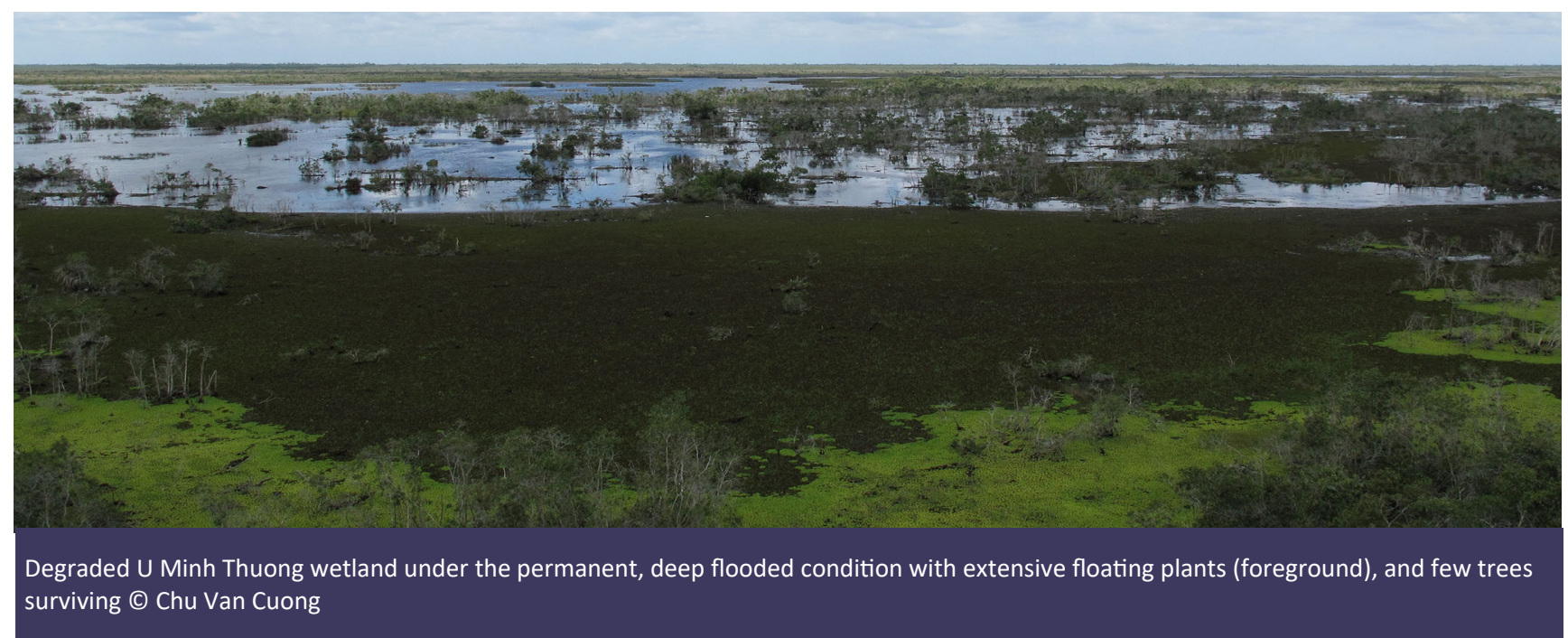


fire led to an urgent but ill-considered management decision from the central government to keep a permanent and deep flood regime in the park through upgrading the existing dyke and dam systems. There were no more forest fires, but the park's ecosystems were affected, particularly the melaleuca forest and avifauna (Dang, 2009; Huong, 2011).

Retaining a permanent, flooded water level higher than the normal conditions for fire prevention negatively impacted on the growth, development and regeneration of the normally seasonally inundated melaleuca forest and other wetland habitats. Many dead seedlings and trees were observed in the park along with water pollution with high nutrient concentration as a consequence of ecosystem and forest degradation (Dang, 2009; Thinh, 2011). This quickly led to a bloom of floating exotic plants such as water hyacinth (Eichhornia crassipes) and water lettuce (Pistia stratiotes) in the canals and open water surface areas in the park. Dense mats of floating exotic plants disturbed the wetland's food web resulting in the death of aquatic species, especially fish (Vinh et al., 2002; Dang, 2009). High flood water levels coupled with the decline of food sources negatively affected wildlife, including birds which rely on the wetland ecosystem for feeding and nesting (Dang, 2009).

\section{Improved water management practice in UMTNP}

Evidence of the wetland degradation in UMTNP from the inappropriate water management regime was presented and discussed at the National Workshop in 2009 (Cuong et al., 2011). The workshop provided an opportunity for the decision makers from central and provincial government, ministries, park managers and scientists to talk about the future management solution to achieve biodiversity restoration and fire management. The official decision to revise the water management system allowed an immediate and permanent draining of the flood water out of the park (Figure 2).

Restoration of the hydrological conditions in the park towards the situation prevailing before the fire in 2002 (see Supplementary Online Material Box 1) enabled recovery of the native vegetation and wetland habitats. This attracted the return of birds to the park for foraging and breeding.

\section{METHODS}

This bird survey is a 'repeat' of previous surveys undertaken in 2009 and 2011, covering the same areas and bird colony. Other surveys were conducted before and after the fire between 1999 and 2002 by Care International (Hoa, 2002). The survey reported here was conducted in 3 weeks from 27 May to 14 June 2013 by two principal researchers from UMTNP who also undertook the previous surveys. Bird species richness in four main habitats of melaleuca forest, open wetland, grassland and nearby buffer zone was recorded using Timed Species Counts and Point Count methods (Pomeroy \& Tengecho, 1986). The number of water birds and populations in the bird colony were investigated using the counting methods from the
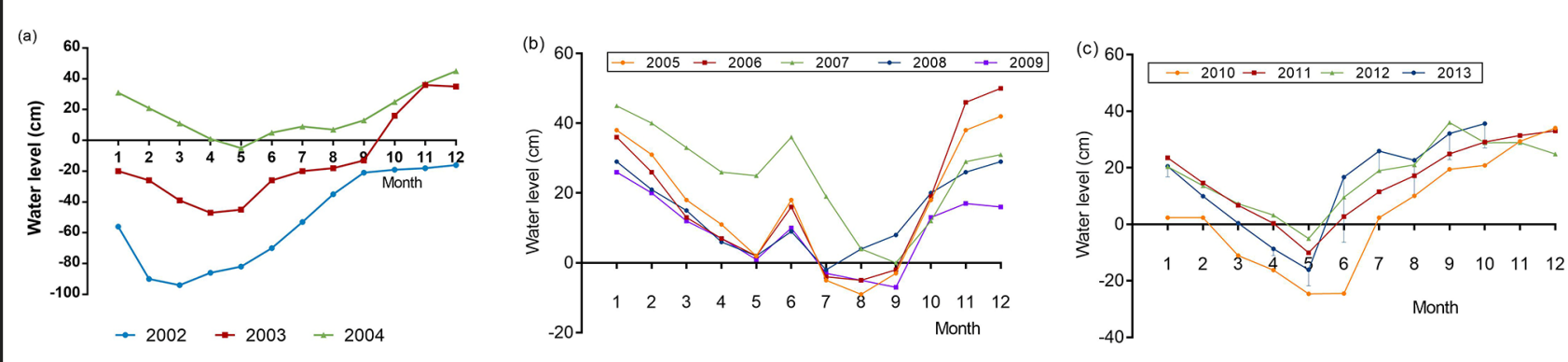

Figure 2. Water level changes in the canals in UMTNP after the fire event in $\mathbf{2 0 0 2}{ }^{\mathbf{1}}$. Figure $2 \mathrm{a}$ shows that the water level was reduced to approximately $90 \mathrm{~cm}$ below ground level as most water in the park was being used for forest firefighting. The water level in the park increased by the end of 2002 under the government decision to flood the park for fire prevention. However, flooding did not occur till the end of 2004 due to the time taken to complete the water management system. Permanent and high water levels occurred from 2005-2009 (Figure 2b) after dyke and gate building was completed allowing retention of all rain water in the UMTNP. Figure $2 \mathrm{c}$ shows changes of flooding condition when flood water in the park was released under improved water management practices since 2010 . Under the new water management scheme, only a certain amount (not all) of the rain water in the rainy season was kept in the park and this created an appropriate (not deep) seasonal flooding in the park (from July to January). The flood water level gradually reduces through evaporation and lateral flow through the dyke walls to outside the park (which had a lower water table), in the hot and dry months and creates a non-flooding season (February to June). 


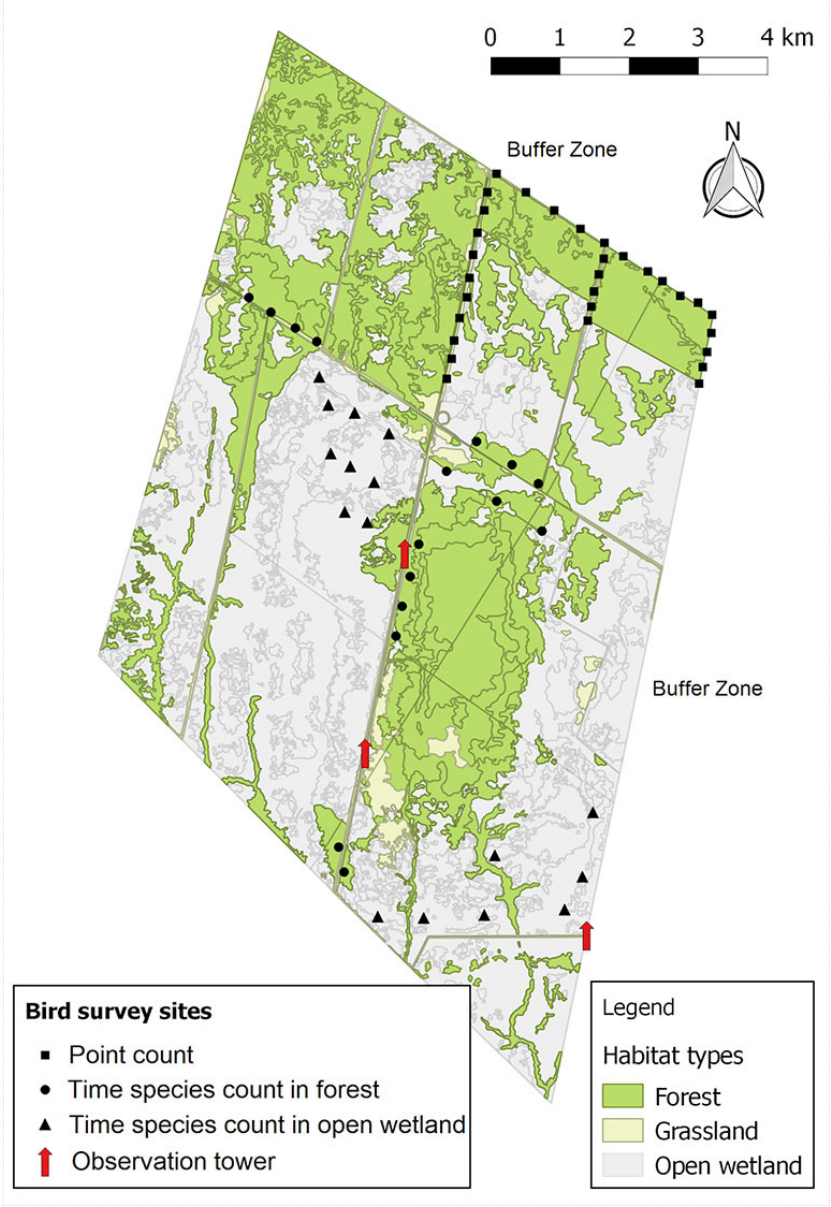

Figure 3. Sites of bird survey in UMTNP and nearby Buffer Zone

observation towers (Figure 3). Bird species were identified and named based on guide books (Quy \& $\mathrm{Cu}$, 1999; Robson, 2011; Hung, 2012). Recorded data for bird richness from the survey was compared with previous surveys in 2011 and particularly the 2009 survey to assess how the new water management regime impacted on the bird species richness of UMTNP and the buffer zone.

\section{Timed Species Counts}

Timed Species Counts (TSC) were undertaken in 32 sample plots of ca. 0.5 ha $(50 \times 100 \mathrm{~m})$ that were set up in the 2009 and 2011 surveys in two main habitats of melaleuca forest and open wetland in the core area of UMTNP (16 plots for each survey habitat). TSC was undertaken in the morning between 06:00-10:00 and in the afternoon between 15:00-18:30. To conduct TSC, the observers walk at a slow pace through the study area for one hour and actively search for birds. During the first ten minutes of the walk all bird species seen are recorded, but only once. In the second ten minutes, all bird species not seen in the first ten minutes are recorded but, again, each different species is only recorded once and this process is repeated for each of the subsequent ten minute blocks until an hour watch is completed.

\section{Point Count}

The Point Count method was used in the grassland habitat because it was impossible for researchers to walk through this habitat to carry out the TSC method. Thirty point count locations were set up with a 3 -metre high aluminium ladder observation platform. Bird species were identified and the number of individuals that were observed within 10 minutes at each counting point recorded in both the core zone and nearby buffer zone.

\section{Counting populations of specific groups}

This method was applied to specific groups of birds such as crane and other water bird species which use the wetland of the park for overnight roosting and breeding. It was used to count stork and night resting waterfowl species and their populations in the bird colony inside the melaleuca forest.

\section{Counting the stork population}

The population of storks (Ciconiidae) was counted four times a day, on 3 continuous days from a $13 \mathrm{~m}$ high observation tower in the core zone of the park. The researchers used binoculars to count lesser adjutant (Leptoptilos javanicus), the main stork species, from the observation tower when they started soaring out of the forest between 10:00-12:00.

\section{Counting night resting water birds}

Water birds were counted in the bird colony inside the melaleuca forest from two main flying directions at two $10 \mathrm{~m}$ high observation towers. Counting of birds flying into the colony was conducted over 3 consecutive days, with 3 periods of 15 minutes' observation followed by a 30 minute break between 16:00-18:30 when birds return to the colony and stay overnight after daily foraging elsewhere. Birds were identified and recorded by species name and the total number of individuals for each counting.

\section{RESULTS}

\section{Bird diversity}

One hundred and fifty-nine bird species belonging to 51 families were recorded in the core zone and buffer zone of UMTNP. Of these, 72 species are waterfowls as classified under the Ramsar Convention, 24 species are wetland forest dependent and 25 are listed as threatened species.

Cotton pygmy-goose (Nettapus coromandelianus) was a first time record in UMTNP. Another five previously recorded species, Indian cormorant (Phalacrocorax 
fuscicollis), greater painted-snipe (Rostratula benghalensis), common snipe (Gallinago gallinago), red turtle dove (Streptopelia tranquebarica) (Safford, 2000) and vinous-breasted starling (Acridotheres burmannicus) (Buckton et al., 1999), which were not observed in the previous surveys in 2003, 2009 and 2011, were found in UMTNP in 2013. Significantly, three threatened bird species: Oriental darter (Anhinga melanogaster), Asian openbill (Anastomus oscitans) and spot-billed pelican (Pelecanus philippensis) which were only observed in the buffer zone between 2004 and 2009 have now returned to the park for feeding and breeding.

Within the core zone of UMTNP, open wetland was the most attractive and appropriate bird habitat. It supported the largest species richness (121 species in 2013) of which 17 species were on the threatened list of
IUCN (2012) and the Vietnam Red Book (Ministry of Science and Technology, 2007). In contrast, melaleuca forest had the lowest bird species richness but it was home to the largest number of specialist bird species (22 species) which are only adapted to this narrow and typical habitat.

The buffer zone provides feeding and resting habitat for 97 bird species, including 9 threatened species. Notably, Oriental darter, Asian openbill and spot-billed pelican are three large-sized threatened bird species facing local poaching. The close proximity and similarity of the habitat characteristics shared between the buffer zone and two habitats (open wetland and grassland) in the core zone of the park resulted in a large proportion of bird species (95 out of 159 species) that chose both the UMTNP and buffer zone as habitats for finding food and resting (Supplementary Online Material, Figure S1).

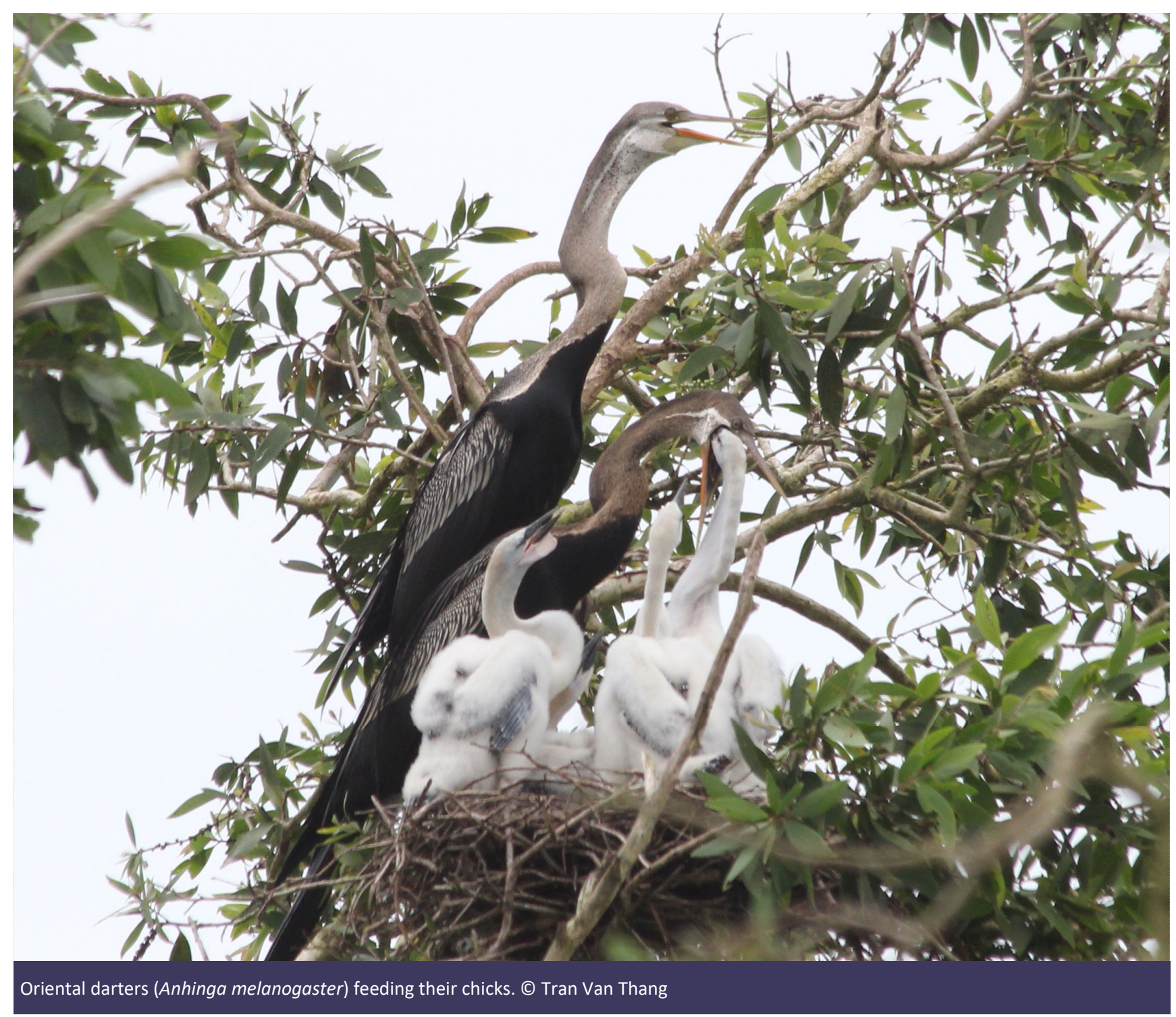


The number of bird species in the buffer zone increased from 95 species in 2003 to 97 species in 2009 and then was unchanged in the 2011 and 2013 surveys. In contrast, bird species richness in the core zone of UMTNP changed following the hydrological condition over the whole period of 2003-2013 (Figure 4). The permanent and deep flooding scheme applied in the park between 2005 and 2009 led to decreased bird species richness (by 27 species in grassland, 19 species in open wetland and 11 species in melaleuca forest) in 2009 (Figure 5). Nearly two years after the application of the new water management scheme that allowed the release of flood water out of the park, the survey results in 2011 showed that bird species richness generally increased. The most recent survey which recorded the cumulative total of species detected over a 10-day assessment in 2013 found the number of bird species increased by 47 in open wetland, by 29 species in grassland and 19 species in melaleuca forest compared to the 2009 assessment.

\section{Bird colony and waterfowl population}

Our study recorded a maximum daily number over a 3day counting period of 19,164 birds comprising 16 water bird species which rested overnight and were breeding in the 10 ha area of the bird colony located in the southeast of the core zone. Of these 16 species, little cormorant (Microcarbo niger), little egret (Egretta garzetta), black-crowned night heron (Nycticorax nycticorax), great egret (Ardea alba) and intermediate egret (Ardea intermedia) were the five main species

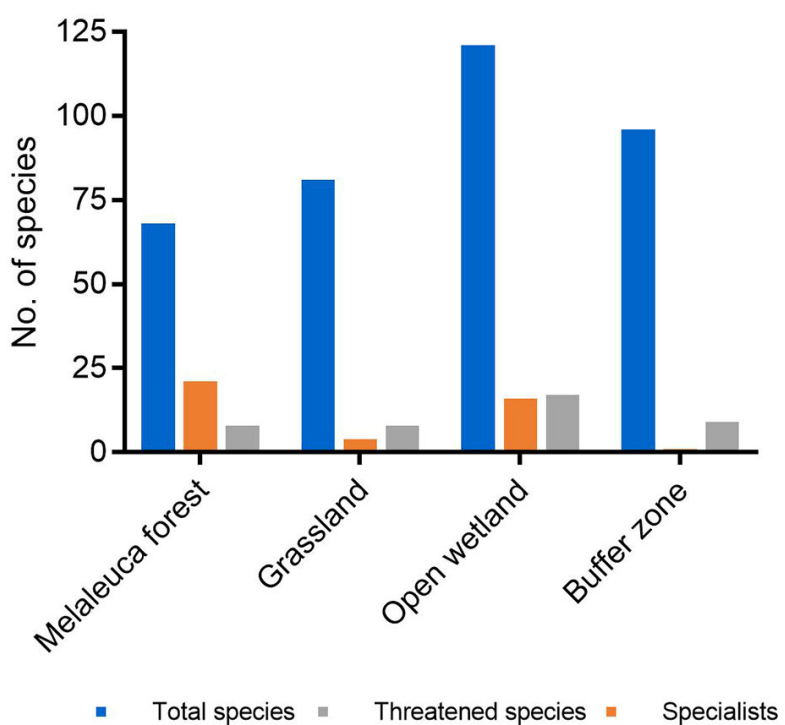

Figure 4. Species composition in each habitat of the core zone of UMTNP and buffer zone
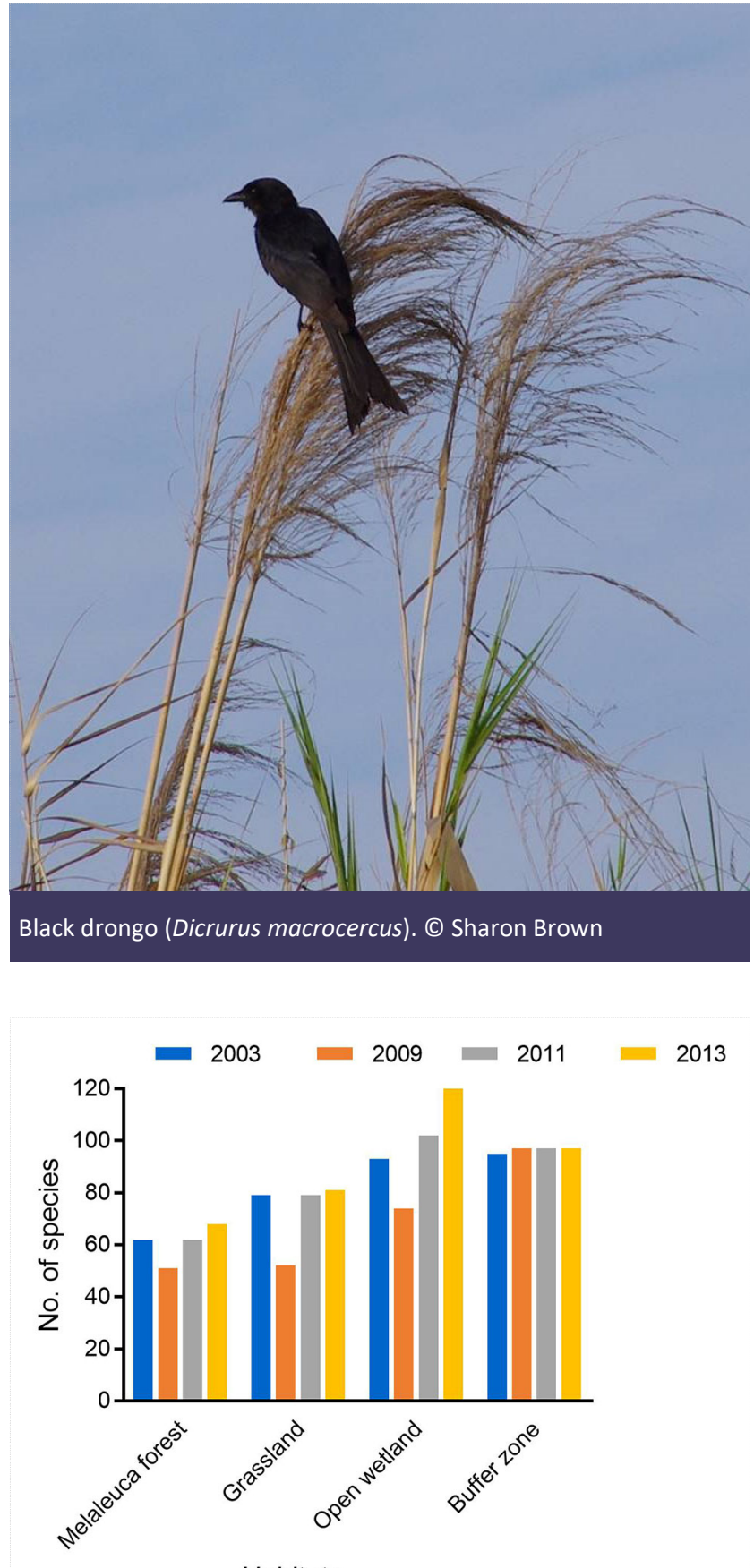

Habitats

Figure 5. Changes in bird diversity in UMTNP and nearby buffer zone from 2003 until 2013. The histogram shows species richness in different habitats in the park and buffer zone after the wildfire in 2002; at the end of a permanent, artificial flooding period (2005-2009) just before an improved water management regime was applied in late 2009. The surveys in 2011 and 2013 were conducted as the melaleuca, open wetland and grassland habitats recovered much of their original ecosystem characteristics (pre the fire and flooding regime) 
commonly observed in the colony (details in Supplementary Online Material, Figure S2).

Waterfowl populations in the bird colony changed following the wildfire and water flooding events. In 2001, 4,418 water birds of 15 species were recorded in the colony (Figure 6). The fire event in 2002 destroyed the colony and nesting places that consequently led to a small decrease in the number of waterfowl species from 15 to 13 with a total bird population decrease from 4,418 to 1,131 birds in 2002. After the fire, all small bird colonies merged into one large colony coupled with an increased area of open wetland that was created with favourable shallows and suitable feeding area as the flooding regime had not yet been instituted. This led to an increase in the bird population of the colony in 2003 to 4,875 waterfowls and a much larger increase in 2004 to a maximum daily total of 23,400 water birds (Figure 6). However, after the long flooding period was instituted in 2005, the waterfowl population decreased by 39 per cent in 2009 compared to 2004 even though the number of species was unchanged. When flood water in the park was released from early 2010 under the new management regime, the water bird population in the colony increased by 26 per cent in 2011 and 33 per cent in 2013 over 2009 levels (Figure 6).

\section{Conservation values}

Twenty-five species have significant conservation issues (Supplementary Online Material, Table S1), being listed either on the International Union for Conservation of Nature Red List (9 species including 2 Vulnerable and 7 Near-threatened) (IUCN, 2012), in the Viet Nam Red Book of 2007 (1 Endangered and 6 Vulnerable species) (Ministry of Science and Technology, 2007), in the CITES Convention and listed under Decree 32/2006/ ND-CP of the Vietnamese Government (11 species) on management of endangered and rare forest plants and animals in Viet Nam (Government of Viet Nam, 2006). Wetlands International (2002) has established criteria for the rareness of water fowl species based on the proportion of species in a habitat as a proportion of the estimated Southeast Asia and world populations. A threshold value of a population of $>1$ per cent is classified as a significantly large population and hence one of interest in terms of species survival and genetic diversity. Seven species: glossy ibis (Plegadis falcinellus), black bittern (Dupetor flavicollis), purple heron (Ardea purpurea), great egret, intermediate egret, spot-billed pelican and little cormorant in UMTNP reach this significant species level.

\section{DISCUSSION}

The diversity of bird species in UMTNP is a reflection of the diversity of habitat types, from melaleuca forest to

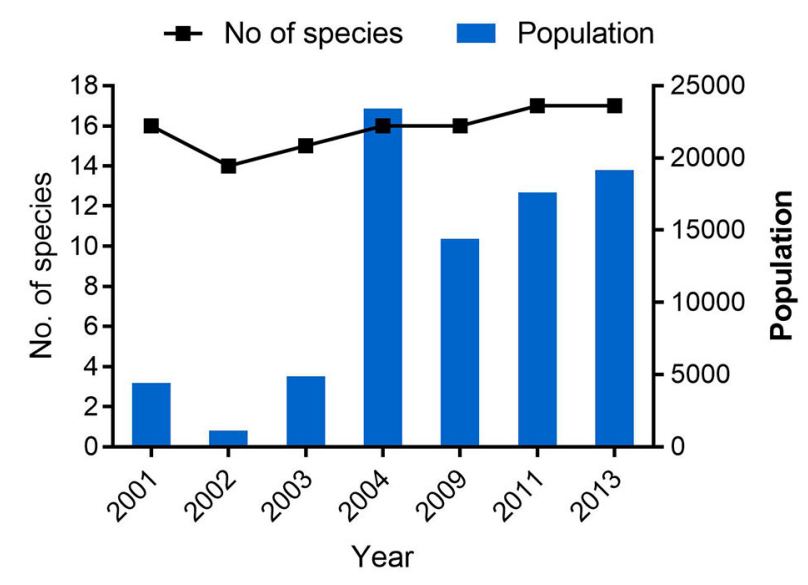

Figure 6. Change of number of waterfowl species and their total population in the bird colony from 20012013

open wetland, grassland and diversified food sources in the buffer zone. As one of eight legally established inland wetland protected areas in the Mekong Delta, UMTNP plays an important role in providing safe habitat and refuge for birds and wildlife in this rapidly changing wetland landscape. Of the 247 bird species recorded in the Mekong Delta (Buckton \& Safford, 2004), UMTNP is home to two-thirds of them. Significantly, the park is home to two-thirds (25 out of 37 species) of the total number of threatened bird species recorded in the Mekong region. However, the disturbance from forest clearance, wildfire and especially the subsequent human imposition of changed hydrological conditions through inappropriate flood water management for fire prevention, negatively impacted bird diversity.

Hydrology plays a vital role in the maintenance of wetland structure and functions (Hollis, 1998; Euliss et al., 2004; Zalewski et al., 2016) and this in turn affects birds that use wetland habitats for feeding, resting and breeding. Like other conservation wetlands in the Mekong Delta (see e.g. Torell et al., 2003; Anh, 2013; Quan et al., 2018), the natural flooding regimes of UMTNP wetland were considerably modified by the establishment of hydraulic infrastructure such as dykes, sluice gates and canals for water management and fire prevention. Fear of wildfire and lack of knowledge about wetland hydrology and dynamics led to inappropriate management decisions which established a permanent flooding regime in the park. The consequence of inappropriate hydrology management practice often leads to wetland restoration failure (Mitsch \& Wilson, 1996), and greatly impacts on wetland birds (Bancroft et al., 2002; O’Neal et al., 2008; Hoover, 2009) and UMTNP is no exception. 


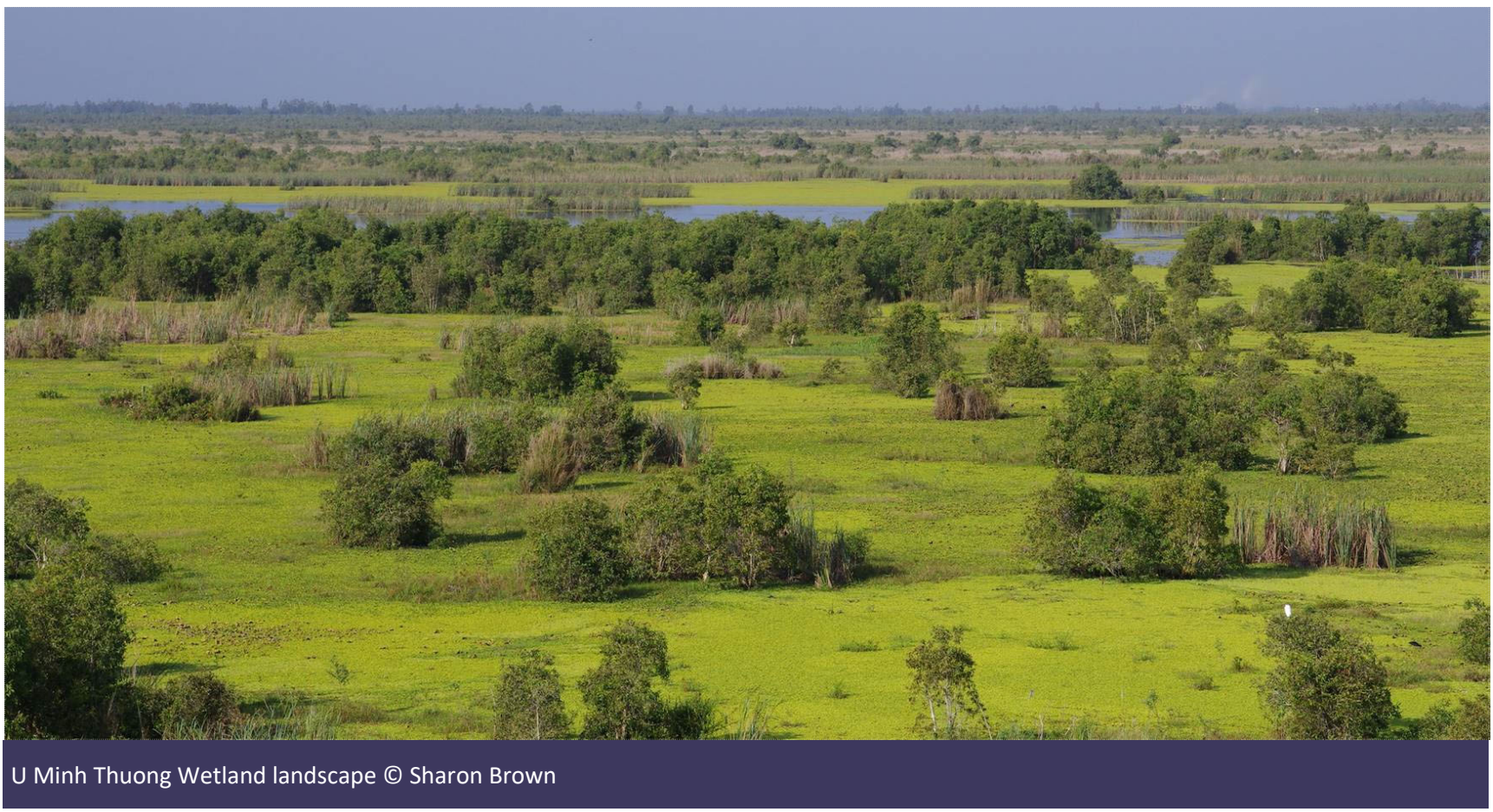

Wetland avifauna is often negatively impacted as a consequence of long-term flooding regime (Kingsford \& Thomas, 2004) and this is the case of UMTNP. A permanent and high flood level established and maintained in the park over a long period from 20052009 led to further degradation of the habitats and food sources post the fire. Especially, the high level flood water negatively affected the prey hunting capacity of water birds (Arengo \& Baldassarre, 1999; Gawlik, 2002). Consequently, many birds were forced to move out of the park leading to the reduction in bird populations during the flooding regime management period.

When the wetland condition was improved from 2010 by allowing the flood water to move out of the park by lowering the canal water level height in order to develop a shallow and seasonally inundated condition, this provided the opportunity for wetland habitats and native vegetation to recover. The survey in 2013 revealed a significant increase in the growth rate of melaleuca trees and the establishment of a newly regenerated seedling population with a density of 320860 seedlings/ha from virtually no trees in the forest area surviving the flooding regime (Thang, 2013). Available food sources provided by re-established natural vegetation apparently then made the wetland habitats attractive destinations again for birds (Davis \& Bidwell, 2008; Matthews \& Endress, 2008). In the case of UMTNP, bird species richness generally increased in the park and typical habitats, and particularly increased in the open wetland areas. This indicates the importance of UMTNP as a safe habitat for birds, being surrounded by the buffer zone habitats which have considerable human disturbance and development activities.

\section{CONCLUSIONS AND MANAGEMENT IMPLICATIONS}

The case of UMTNP shows that wetland habitats in the Lower Mekong Delta need the seasonal change of flood water height and a dry season without floodwater, as now occurs again in the natural wetlands of UMTNP, to enable their unique habitats, especially melaleuca forests, to survive and prosper. The positive response of avifauna to the changes in U Minh Thuong indicates the need to understand how the 'normal' wetland processes operate in support of biodiversity conservation before modifying them for fire management. The attempt to save the melaleuca forest failed because the permanent flooded condition killed the trees. Thus, wetland conservation policy and management practice needed to be changed from focusing on an attempt to preserve tree species from fire based on a deep and permanent flood regime, to applying an integrated water and fire prevention strategy.

Fire should be used as an ecological management tool for promoting forest succession and regeneration, and maintaining and conserving a healthy wetland. Although fire is an important ecological factor affecting the development of, and succession within, the melaleuca forest ecosystem (Ngan \& Hien, 1987), its use is 
prohibited in protected area management in Viet Nam. Thus, implementation of an integrated fire and wetland water management strategy enabling prescribed burning, as was discussed and concluded to be beneficial in the participatory national workshop (Cuong et al., 2011; Quynh, 2011), would facilitate forest regeneration and reproduction that provide food sources for seed eating birds (de Szalay \& Resh, 1997). Controlled burning helps to remove and/or decrease plant litter, woody or invasive species, particularly fireprone grass material such as Phragmites vallatoria that grows quickly and accumulates under appropriate tropical conditions, and controlled burning is likely to modify the plant species composition and may develop a habitat that better supports wetland birds (Kirby et al., 1988; Brennan et al., 2005).

It is necessary to maintain the habitat diversity and appropriate habitat ratio of melaleuca forest, open wetland and grassland within the park for avifauna and wildlife conservation. Although grassland and open wetland are important habitats to support both bird diversity and species of high conservation value, these two habitats are often considered as 'waste land' and are under high risk of disturbance from invasive plants and management intervention such as reforestation. Given that planting trees could assist in restoring wetland vegetation and control exotic plants and grasses, this activity paradoxically often increases the risk of habitat loss and disturbance, and displaces birds (Allan et al.,
1997). Consequently, birds will be forced to forage outside of the park (e.g., buffer zones, agricultural and aquaculture land) where they are subject to poaching and could become endangered.

Protection of birds in the protected area wetlands is a highly recommended management strategy (Erwin, 2002), but conservation efforts need to be implemented at landscape level in the park and surrounding agricultural buffer zones. Available food sources from diverse crops and aquaculture production in the buffer zone may make it more attractive for birds, including threatened species to find food there. In contrast to the strict protection level in the park, birds in the buffer zone and farming areas are often under threat from local poaching activity. Thus, conservation in a catchment encompassing a national park or protected area requires implementation of an awareness programme for local communities which outlines the importance of conservation to the overall ecosystem biodiversity and sustainability, and thus the communities' economic long -term wellbeing.

\section{SUPPLEMENTARY ONLINE MATERIAL}

Box 1 Improved Water management regime in U Minh Thuong National Park

Figure S1. Multidimensional scaling following the presence and absence of bird species in 5 different habitats

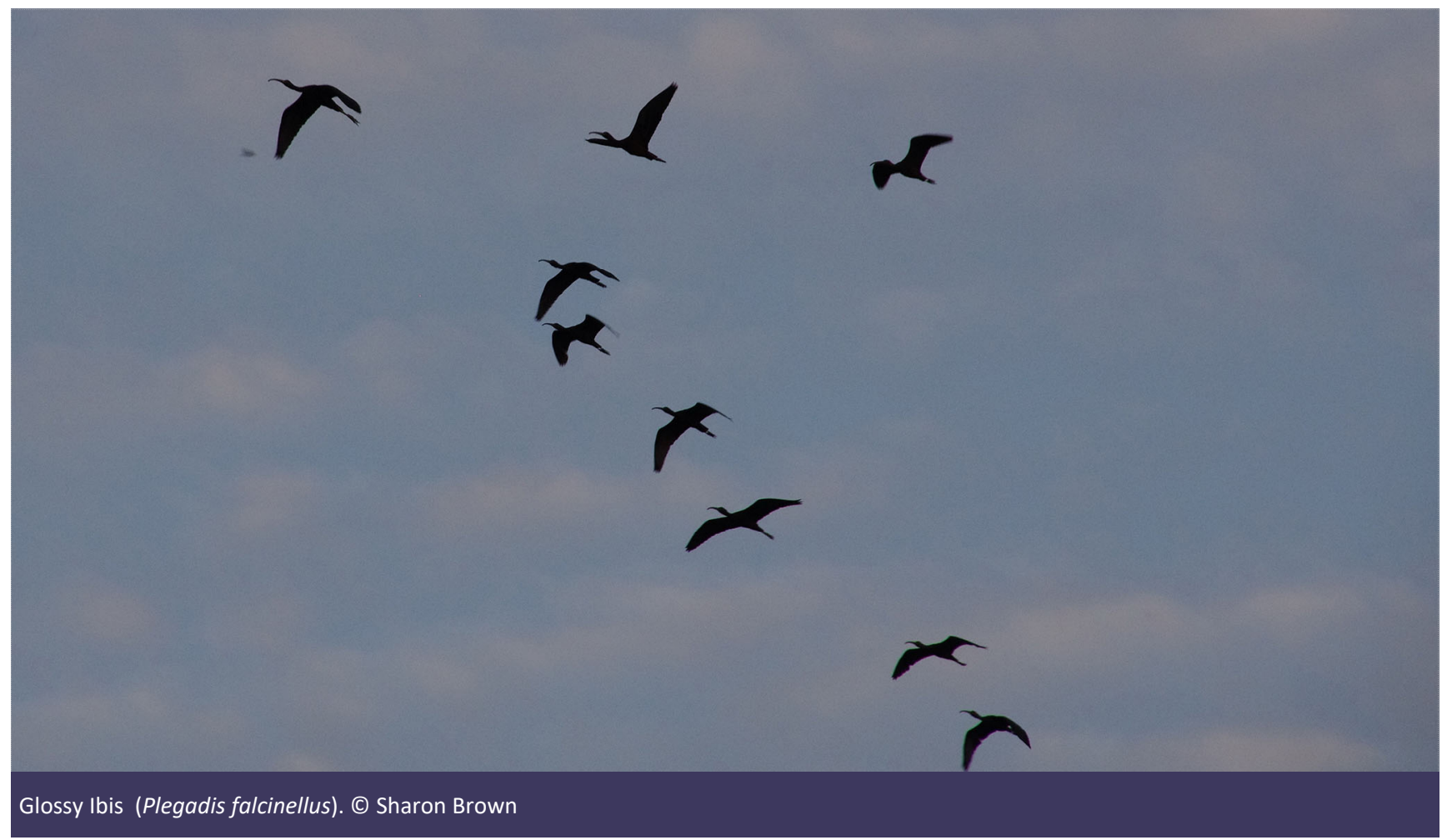


Figure S2. Number of significant bird colony waterfowl species present at the peak in May 2013

Table S1. Bird species of conservation importance in U Minh Thuong National Park

\section{ACKNOWLEDGEMENT}

We thank the GIZ/DFAT Conservation and Development of the Kien Giang Biosphere Reserve Project for funding this study.

\section{ABOUT THE AUTHORS}

Chu Van Cuong completed a $\mathrm{PhD}$ degree at the School of Earth and Environmental Sciences, The University of Queensland, Australia. His working experience and research interests focus on National Park and Biosphere Reserve management, effectiveness evaluation, forest restoration and community development (ORCID id: 000o-0001-9276-470X).

Peter Dart is Honorary Associate Professor at the School of Agriculture and Food Sciences, The University of Queensland. His research involves the management of Protected Areas and Biosphere Reserves particularly in the Philippines and Viet Nam. He also works on the management of coastal zones and stabilising mangrove forests and their restoration.

Sharon Brown was former Chief Technical Advisor of the Conservation and Development of the Kien Giang Biosphere Reserve Project. Dr Brown has over 20 years' working experience on forestry, protected areas management and community development in Viet Nam, Philippines, Cambodia and Laos.

Tran Van Thang is a department head of U Minh Thuong National Park, Viet Nam. He has over 15 years' working and research experience in biodiversity conservation, bird monitoring, forest management and restoration, wetland hydrology and peatland management, and community development.

Vo Thi Minh Le is Deputy Director of the Center for Greater Mekong Subregion Cooperation Studies, Institute of World Economics and Politics, Viet Nam Academy of Social Sciences. Holding a PhD degree in International Economics and a Master's degree in Development Practice, she has been involved in many research projects on sustainable economic management models and development, trade, investment, environmental management and water security, and monitoring disaster risks in the Mekong region.

\section{REFERENCES}

Allan, D.G., Harrison, J.A., Navarro, R.A., van Wilgen, B.W. and Thompson, M.W. (1997). The impact of commercial afforestation on bird populations in Mpumalanga Province, South Africa - Insights from Bird-Atlas data. Biological Conservation, 79(2-3): 173-185. https://doi.org/10.1016/ S0006-3207(96)00098-5.

Anh, V.T. (2013). Enhancing forest fire prevention measures for $U$ Minh peatland areas of Kien Giang and Ca Mau. Viet Nam component report: Rehabilitation and Sustainable Use of Peatland Forests in Southeast Asia Project.

Arengo, F. and Baldassarre, G.A. (1999). Resource variability and conservation of American Flamingos in coastal wetlands of Yucatan, Mexico. Journal of Wildlife Management, 63(4): 1201-1212. https://www.jstor.org/stable/3802838.

Bancroft, G.T., Gawlik, D.E. and Rutchey, K. (2002). Distribution of wading birds relative to vegetation and water depths in the Northern Everglades of Florida, USA. Waterbirds, 25: 265$277 . \quad$ https://doi.org/10.1675/1524-4695(2002)025 [0265:DOWBRT]2.0.CO;2.

Bao, T.Q. (2011). Study appropriate flooding level for fire prevention and maintenance melaleuca forest development in $U$ Minh Thuong and $U$ Minh Ha National Parks. Institute of Forest Ecology and Environment.

Biggs, D. (2005). Managing a rebel landscape: Conservation, pioneers, and the revolutionary past in the $U$ Minh forest, Viet Nam. Environmental History, 10(3): 448-476. https:// www.jstor.org/stable/3985999.

Biggs, D. (2011). Fixing the Delta: History and the Politics of Hydraulic Infrastructure Development and Conservation in the Mekong Delta. In: M.A. Stewart and P.A. Coclanis (eds.), Environmental Change and Agricultural Sustainability in the Mekong Delta, pp. 35-44. Advances in Global Change Research 45.

Bobbink, R., Whigham, D.F., Beltman, B. and Verhoeven, J.T.A. (2006). Wetland functioning in relation to biodiversity conservation and restoration. In: R. Bobbink, B. Beltman, J.T.A. Verhoeven and D.F. Whigham (eds.) Wetlands: Functioning, biodiversity conservation, and restoration, pp. 112., Berlin, Heidelberg, New York: Springer.

Brennan, E.K., Smith, L.M., Haukos, D.A. and LaGrange, T.G. (2005). Short-term response of wetland birds to prescribed burning in rainwater basin wetlands. Wetlands, 25(3): 667674. https://doi.org/10.1672/0277-5212(2005)025 [0667:SROWBT]2.0.CO;2

Buckton, S.T. and Safford, R.J. (2004). The avifauna of the Vietnamese Mekong Delta. Bird Conservation International, 14(4): 279-322. https://doi.org/10.1017/S0959270904000346.

Buckton, S.T., Cu, N., Quynh, H.Q. and Tu, N.D. (1999). The conservation of key wetland sites in the Mekong Delta. Hanoi: BirdLife International Vietnam Programme.

Care (2001). Soil mapping, land evaluation and land use planning of the Buffer Zone of the $U$ Minh Thuong Natural Reserve. $\cup$ Minh Thuong Natural Reserve Conservation and Community Development Project.

Chandler, G., Yen, N.T.H., Larsen, I.B., Tri, H.M., Phong, V.V. and Hoa, N.P.B. (2000). Socio-economic appraisal on the community surrounding the $U$ Minh Thuong Natural Reserve 1999-2000. U Minh Thuong Nature Reserve Conservation and Community development Project. 
Cuong, C.V., Hai, L.T. and Giang, L.T. (2011). Conservation and sustainable development of the $U$ Minh Thuong National Park. Ho Chi Minh City, Viet Nam: Agriculture Publishing House.

Dang, N.X. (2009). Rapid assessment of flora and terrestrial animals in Key Areas of the Kien Giang Biosphere Reserve. German Technical Cooperation and Kien Giang Biosphere Reserve Project.

Davidson N.C. (2014). How much wetland has the world lost? Long-term and recent trends in global wetland area. Marine and Freshwater Research, 65(10): 934-941. https:// doi.org/10.1071/MF14173.

Davis, C.A. and Bidwell, J.R. (2008). Response of aquatic invertebrates to vegetation management and agriculture. Wetlands, 28(3): 793-805. https://doi.org/10.1672/07-156.1.

de Szalay, F.A. and Resh, V.H. (1997). Responses of wetland invertebrates and plants important in waterfowl diets to burning and mowing of emergent vegetation. Wetlands, 17(1): 149-156. https://doi.org/10.1007/BF03160726.

Dzung, P.V. (2002). Introduction to U Minh Thuong National Park. In: N.X. Vinh, N.X. Dang and H. Sasaki (eds.) Workshop on enhancement of knowledge and conservation of otters in $U$ Minh Thuong National Park, pp. 61-66. Kien Giang, Viet Nam.

Dzung, P.T. and Co, P.N. (2011). Environmental changes after forest fire at $U$ Minh $\mathrm{Ha}$ and $U$ Minh Thuong and recommendations for forest restoration. In: C.V. Cuong, L.T. Hai and L.T. Giang (eds.) Conservation and Sustainable Development of U Minh Thuong National Park, pp. 95-109. Ho Chi Minh City, Viet Nam: Agriculture Publishing House.

Erwin, R.M. (2002). Integrated management of waterbirds: Beyond the conventional. Waterbirds, 25(suppl. 2): 5-12. http:// www.jstor.org/stable/1522447.

Euliss, N.H. Jr., LaBaugh, J.W., Fredrickson, L.H., Musher, D.M., Laubhan, M.K., Swanson, G.A., Winter, T.C., Rosenberry, D.O. and Nelson, R.D. (2004). The wetland continuum: A conceptual framework for interpreting biological studies. Wetlands, 24(2): 448-458. https://doi.org/10.1672/0277-5212 (2004)024[0448:TWCACF]2.0.CO;2.

Gawlik, D.E. (2002). The effects of prey availability on the numerical response of wading birds. Ecological Monographs, 72(3): 329-346. https://doi.org/10.1890/0012-9615(2002)072 [0329:TEOPAO]2.0.CO;2.

Government of Viet Nam (2006). The Government Decree No. 32/2006/ND-CP on Management of Endangered, Rare and Precious Plants and Animals. Ha Noi.

Hashimoto, T.R. (2001). Environmental Issues and Recent Infrastructure Development in the Mekong Delta: Review, analysis and recommendations with particular reference to large scale water control projects and the development of coastal areas. Working Paper No. 4. Australia: Australian Mekong Resource Centre, University of Sydney..

Hawa, A., Azhar, B., Top, M.M. and Zubaid, A. (2016). Depauperate avifauna in tropical peat swamp forests following logging and conversion to oil palm agriculture: Evidence from mist-netting data. Wetlands, 36(5): 899-908. https://doi.org/10.1007/s13157-016-0802-3

Hoa, N.P.B. (2002). Bird monitoring report. U Minh Thuong National Park and Community Development Project.

Hoang, N.H., Dargusch, P., Moss P. and Aziz, A.A. (2017). Landuse change and socio-ecological drivers of wetland conversion in Ha Tien Plain, Mekong Delta, Viet Nam. Land Use Policy, 64: 101-113. https://doi.org/10.1016/ j.landusepol.2017.02.019

Hollis, G.E. (1998). Hydrological data for wetland management. Water and Environment Journal, 12(1): 9-17. https:// doi.org/10.1111/j.17476593.1998.tb00140.x

Hoover, J.P. (2009). Effects of hydrologic restoration on birds breeding in forested wetlands. Wetlands, 29(2): 563-573. https://doi.org/10.1672/08-75.1

Hung, L.M. (2012). Introduction of Viet Nam birds. Ha Noi, Viet Nam: Natural Science and Technology Publishing House.

Huong, L.H. (2011). Water management plan for conservation and development of $U$ Minh Thuong National Park. In: C.V. Cuong, L.T. Hai and L.T. Giang (eds.) Conservation and Sustainable Development of U Minh Thuong National Park, pp. 138-151. Ho Chi Minh City, Viet Nam: Agriculture Publishing House.

IUCN (2012). IUCN Red List Categories and Criteria: Version 3.1. Second edition. International Union for Conservation of Nature: Gland, Switzerland and Cambridge, UK.

Kien Giang Province People's Committee (2005). Kien Giang Biosphere Reserve. Proposal report to UNESCO.

Kingsford, R.T. and Thomas, R.F. (2004). Destruction of wetlands and waterbird populations by dams and irrigation on the Murrumbidgee River in arid Australia. Environmental Management, 34 (3): 383-396. https://doi.org/10.1007/s00267 $-004-0250-3$

Kirby, R.E., Lewis, S.J. and Sexon, T.J. (1988). Fire in North American wetlands ecosystems and fire-wildlife relations: An annotated bibliography. Washington, DC, USA: U.S. Fish and Wildlife Service, Office of Biological Services. FWS/OBS-88/1.

Matthews, J.W. and Endress, A.G. (2008). Performance criteria, compliance success, and vegetation development in compensatory mitigation wetlands. Environmental Management, 41(1): 130-141. https://doi.org/10.1007/s00267007-9002-5.

Millennium Ecosystem Assessment (2005). Ecosystems and Human Well-being: Wetlands and Water Synthesis. Washington, DC: World Resources Institute.

Ministry of Science and Technology (2007). Red data book of Viet Nam. Volume 1, Hanoi: Animal. Science and Technics Publishing House.

Mitsch, W.J. and Wilson, R.F. (1996). Improving the success of wetland creation and restoration with know-how, time, and self -design. Ecological Applications, 6: 77-83. https:// doi.org/10.2307/2269554.

Ngan, P.T. and Hien, C.Q. (1987). Viet Nam inundated forests. Hanoi: Education Publishing House.

Nuwer, R. and Bell, D. (2014). Identifying and quantifying the threats to biodiversity in the $U$ Minh peat swamp forests of the Mekong Delta, Viet Nam. Oryx, 48(1): 88-94. https:// doi.org/10.1017/S0030605312000865.

O'Neal, B.J., Heske, E.J. and Stafford, J.D. (2008). Waterbird response to wetlands restored through the conservation reserve enhancement program. Journal of Wildlife Management, 72(3): 654-664. https://doi.org/10.2193/2007165.

Pomeroy, D.E. and Tengecho, B. (1986). Studies of birds in semiarid areas of Kenya. III: The use of 'Time species count' for studying regional avifaunas. Journal of Tropical Ecology, 2(3): 231-247. https://www.jstor.org/stable/2559854. 
Quan, N.H., Toan, T.Q., Dang, P.D., Phuong, N.L., Anh, T.T.H., Quang, N.X., Quoc, D.P., Quoi, L.P., Hanington, P. and Sea, W.B. (2018). Conservation of the Mekong Delta wetlands through hydrological management. Ecological Research, 33: 87-103 DOI 10.1007/s11284-017-1545-1.

Quy, V. and Cu, N. (1999). Bird list of Viet Nam. Ha Noi: Agriculture Publishing House.

Quynh, V.V. (2011). Points of views and water management solutions for fire prevention in $U$ Minh Thuong National Park. In: C.V. Cuong, L.T. Hai and L.T. Giang (eds.) Conservation and Sustainable Development of $U$ Minh Thuong National Park, pp. 131-137. Ho Chi Minh City, Viet Nam: Agriculture Publishing House.

Robson, C. (2011). A field guide to the birds of South East Asia. London: New Holland Publishers.

Safford, R. (2000). A manual for U Minh Thuong: Habitat and biodiversity monitoring.

Sanders, B.M. (2002). Fire Incident Assessment: U Minh Ha Forest and U Minh Thuong National Park Ca Mau and Kien Giang Provinces, Viet Nam.

Thang, T.V. (2013). Vegetation survey in U Minh Thuong National Park. Technical report to Conservation and Development of the Kien Giang Biosphere Reserve.

Thinh, P.T. (2003). Findings from Wetlands Classification and Inventory of Wetlands/Aquatic Ecosystem in the Mekong Basin Viet Nam. Mekong River Commission.

Thinh, P.T. (2011). Biodiversity of U Minh Thuong National Park and solutions to conserve and manage Melaleuca forest on peat land. In: C.V. Cuong, L.T. Hai and L.T. Giang (eds.) Conservation and Sustainable Development of $U$ Minh Thuong National Park, pp. 33-50. Ho Chi Minh City, Viet Nam: Agriculture Publishing House.

Torell, M., Salamanca, A.M. and Ratner, B.D. (2003). Wetlands management in Viet Nam: Issues and perspectives. Penang: World Fish Center.
Tuyen, L.H. (2013). Socio-economic situation of the households in the Buffer Zone of U Minh Thuong National Park.

Viet Nam Environment Protection Agency (2005). Evaluation of multi-sectoral policy, law and legal framework for wetland management in Viet Nam. Ministry of Natural Resources and Environment.

Vinh, N.X., Dan, P.Q. and Tuyen, L.H. (2002). Otters and exotic plants in U Minh Thuong National Park. In: N.X. Vinh, N.X, Dang and $\mathrm{H}$, Sasaki (eds.). Enhancement of Knowledge and Conservation of Otters in $U$ Minh Thuong National Park, pp. 75-81. Viet Nam.

Wetlands International (2002). Waterbird Population Estimates. Third Edition. S. Delany and D. Scott (eds.) Wetlands International Global Series No. 12. Wageningen, The Netherlands: Wetlands International.

Yule, C.M. (2010). Loss of biodiversity and ecosystem functioning in Indo-Malayan peat swamp forests. Biodiversity and Conservation, 19(2): 393-409. https://doi.org/10.1007/s10531 $-008-9510-5$

Zalewski, M., McClain, M. and Eslamian, S. (2016). Ecohydrology - the background for the integrative sustainability science. Ecohydrology and Hydrobiology, 16(2): 71-73. https:// doi.org/10.1016/j.ecohyd.2016. 04.003

Zedler, J.B. and Kercher, S. (2005). Wetland Resources: Status, Trends, Ecosystem Services, and Restorability. Annual Review of Environment and Resources, 30: 39-74. https:// doi.org/10.1146/annurev.energy.30.050504.144248 


\section{RESUMEN}

El Parque Nacional U Minh Thuong, uno de los dos humedales turbosos de Melaleuca más grandes que quedan en Vietnam, es un área de gran importancia para la conservación de las aves debido a sus diversos hábitats de humedales. Un devastador incendio forestal en 2002 dio lugar a un nuevo régimen de control de incendios basado en un régimen permanente de inundación impuesto en grandes áreas del parque que provocó una degradación extrema de los humedales y los bosques. Esto a su vez afectó de manera negativa tanto la diversidad como las poblaciones de especies de aves. En 2009, el Gobierno de Vietnam y la Autoridad del Parque adoptaron una práctica mejorada de gestión del agua. Un estudio realizado cuatro años más tarde registró dos nuevas especies en la lista de 159 especies de aves que habitan en el parque. De estas, 25 especies amenazadas utilizaban los humedales y la zona de amortiguamiento adyacente como hábitat para su desarrollo y alimentación. Con base en el mayor registro ocurrido durante tres días consecutivos, la población de aves acuáticas en la colonia de aves en 2013 aumentó en un 33 por ciento en comparación con el nivel de 2009. La respuesta positiva de la avifauna a los cambios en U Minh Thuong con respecto a la hidrología de los humedales turbosos de Melaleuca inundados estacionalmente, indica la necesidad de comprender cómo intervienen los procesos "normales" de los humedales en apoyo de la conservación de la biodiversidad antes de modificarlos para el control de incendios.

\section{RÉSUMÉ}

Le parc national d'U Minh Thuong est l'une des deux plus grandes tourbières marécageuses restantes au Viet Nam, comprenant des prairies saisonnièrement inondées et des forêts de Melaleuca qui constituent une zone très importante pour la conservation des oiseaux en raison de la diversité de ses habitats humides. Un incendie de forêt dévastateur en 2002 a entrâné la mise en place de nouvelles mesures de prévention contre les incendies consistant en un régime obligatoire d'inondation permanente sur de vastes zones du parc, ce qui a entraîné une grave dégradation des zones humides et des forêts. Cela a eu un impact négatif sur les populations d'oiseaux et sur leur diversité. En 2009, le gouvernement du Viet Nam et les autorités du parc ont adopté une pratique améliorée de gestion de l'eau. Le résultat d'une enquête menée quatre ans plus tard a permis d'ajouter deux nouvelles espèces sur la liste des 159 espèces d'oiseaux du parc. Parmi celles-ci figurent 25 espèces menacées habitant et se nourrissant dans les zones humides du parc et la zone tampon adjacente. Selon le plus grand recensement pratiqué sur trois jours consécutifs, la population d'oiseaux d'eau a augmenté de 33\% en 2013 par rapport au niveau de 2009. Cette réaction positive de l'avifaune à U Minh Thuong grâce à la pratique améliorée du régime d'hydrologie des forêts de Melaleuca saisonnièrement inondées, souligne la nécessité d'une prise en compte du fonctionnement «normal» des zones humides et de son rôle dans la conservation de la biodiversité, avant toute modification pour la gestion des incendies. 